\title{
Hemagglutination and Structural Polypeptides of a New Coronavirus Associated with Diarrhea in Iniant Mice
}

\author{
By \\ K. SugiYama and Y. Amano \\ Department of Microbiology and Central Laboratory, \\ Akita University Sehool of Medicine, \\ Akita, Japan \\ With 4 Figures \\ Accepted April 29, 1980
}

\begin{abstract}
Summary
The hemagglutination (HA) and receptor destroying enzyme (RDE) activities of a newly isolated mouse enteric coronavirus (designated as DVIM) are described. DVIM agglutinates mouse or rat red blood cells $(\mathrm{RBC})$ at $4^{\circ} \mathrm{C}$. At $37^{\circ} \mathrm{C}$ the agglutination was rapidly reversed. The optimal $\mathrm{pH}$ for $\mathrm{HA}$ and for $\mathrm{RDE}$ activities using mouse red cells were shown to be 6.5 and 7.3 respectively. Hemagglutination by DVIM was not inhibited by pretreatment of RBCs with Vibrio cholerae filtrate or by pretreatment with Influenza-A neuraminidase. Therefore, the DVIM receptors on $\mathrm{RBCs}$ differ from the receptors of Influenza-A, and the RDE activity of DVIM acts specifically on this receptor.

In addition, an analysis of the DVIM polypeptides showed that the virions contain five major, VP1 (M.W. 139,000), VP2 $(68,000)$, VP3 $(53,000)$, VP4 $(38,000)$, VP5 $(22,000)$ and two minor, VP1 a $(110,000)$, VP1b $(100,000)$ polypeptides. VP1 and VP1 b were digested by bromelain, suggesting that they constitute the surface glycoproteins.
\end{abstract}

\section{Introduction}

Coronaviridae are a family of lipid-containing RNA viruses which exhibit a unique morphology. The virions have widely-spaced surface projections which form a radiating "corona" around the particles as shown by electron microscopy $(18,26)$. The diarrhea virus of infant mice (DVIM), a newly-isolated mouse enteric coronavirus, is antigenically related to other coronaviruses by complement fixation assay but clearly distinguishable by neutralization assay (21).

The existence of a receptor destroying enzyme (RDE)-like activity has not been reported for any of the coronaviruses. We report here a RDE activity associated with DVIM virions which differs from that of ortho- or paramyxo- 
viruses. The struotural polypeptides of DVIM were analysed by polyacrylamide gel electrophoresis.

\section{Materials and Methods}

\section{Virus and Purification}

The mouse enteric coronavirus (DVIM) was kindly provided by Dr. Kozaburo Sato (Central Laboratory of Shionogi Pharm. Co., Osaka, Japan). DVIM was passaged in BALB/e-3T 3 cell cultures in Eagle's minimal essential medium containing 10 percont fetal calf serum. Virus inoculation was carried out with $10^{7}$ TCID $_{50}$ per Roux bottle. At 24 hours post-infection virus was harvested by three freeze-thaw cycles and stored at $-70^{\circ} \mathrm{C}$. Influenza virus strain $\mathrm{A} / \mathrm{RI} / 5, \mathrm{~A} /$ Victoria/3/75, $\mathrm{A} / \mathrm{NJ} / 8 / 76$ and Hemagglutinating virus of Japan (HVJ or Sendai virus) strain Z were grown in the allantoie cavity of 10-day old embryonated chicken eggs as previously described (24). The same purification processes were employed for each virus at $4^{\circ} \mathrm{C}$. Alter clarification of culture fluid by centrifugation at $8,600 \times g$ for 30 minutes, virions were concentrated by centrifugation at $70,000 \times g$ for 90 minutes, resuspended in $0.1 \mathrm{M} \mathrm{NTE}$ buffer (0.05 M Tris-Cl, $0.1 \mathrm{M} \mathrm{NaCl}, 0.001 \mathrm{M}$ EDTA), $\mathrm{pH} 7.3$, layered onto a discontinuous gradient of sucrose $(15: 30: 50$ percent $w / w)$, and centrifuged at $64,000 \times g$ for 2 hours. Virions were collected from the interphase between 30 and 50 percent sucrose solutions and were dialysed against NTE buffer. For polypeptide analysis, virions were repurified by linear sucrose gradient (20 to 50 percent $w / w$ ) centrifugation at $77,000 \times g$ for 90 minutes.

\section{Hemagglutination (HA) Assay}

Routine HA tests were carried out as previously described (23), using 0.5 percent mouse RBCs in Dulbecco's PBS, containing 0.3 percent bovine serum albumin. Alternatively, 0.25 percent avian $\mathrm{RBCs}$, or 0.5 percent other mammalian $\mathrm{RBCs}$ were used. The titer was recorded as the reciprocal of the highest virus dilution causing a detectable HA.

\section{Hemadsorption}

Hemadsorption tests were done on DVIM-infected BALB/e-3T3 cell monolayers grown on glass cover slips. A 0.5 percent suspension of mouse RBCs were adsorbed for 3 hours at $44^{\circ} \mathrm{C}$. Cover slips were washed and prepared for analysis by light microscopy. The experiment for elution kinetics was performed on identical cell-monolayers at various incubation periods. To test for RDE-like activity, cells were incubated at indicated temperatures, prepared for microscopy and photographed. The elution ratio was expressed as the percentage of remaining $R B C$ Cs enumerated per photographic field.

\section{Polyacrylamide Gel Wlectrophoresia (PAGE)}

Sodium dodecyl sulfate (SDS)-PAGE was performed on 7.5 percent polyacrylamide gels by the method of MArzer et al. (17), using $6 \mathrm{~mm}$ diameter tubular gels $60 \mathrm{~mm}$ long. Purified virus was solubilized in 1 percent SDS, 1 percent 2-mereaptoethanol, 20 percent glycerol, and 0.006 percent bromphenol blue, for 1.5 minutes at $100^{\circ} \mathrm{C}$. After preelectrophoresis for one hour at $5 \mathrm{~mA} / \mathrm{gel}$, samples were applied and electrophoresis was carried out at $5 \mathrm{~mA} / \mathrm{gel}$ in 0.1 in sodium phosphate buffer, $\mathrm{pH} 7.2$, for 6 hours, at room temperature.

Gels were fixed overnight with 20 percent sulfosalicylic acid and stained with 0,25 pereent Coomassie brilliant blue in 50 pereent methanol. The gels were destained with several changes of 15 percent methanol in 7 percent acetio acid. Gels were stained for carbohydrate and lipid with Schiff's reagent and oil-red-O, respectively, following the methods of Hromolzzir et al. (8). Stained gels were scanned with a densitometer (Joko gel scamner) at $600 \mathrm{~nm}$ for peptides, $550 \mathrm{~nm}$ for carbohydrates, and $450 \mathrm{~nm}$ for lipids, respeetively.

The approximate molecular weights of the polypeptides were determined by the method of SHApIro et at. (22). Percentage composition of each structural polypeptide was determined from the photometric scans using a Joko scanning planimeter. 


\section{Results}

\section{Characterization of Hemagglutination Activity of DVIM}

Red blood cells of seven different species were tested for agglutinability with DVIM, and the results are summarized in Table 1 . Only mouse and rat RBCs were agglutinated at $4^{\circ} \mathrm{C}$, indicating a restricted receptor range for the $\mathrm{HA}$ activity.

Mouse RBCs agglutinated by DVIM at $4^{\circ} \mathrm{C}$, could be liberated from agglutination by incubation at $20^{\circ} \mathrm{C}$ (Table 2). The DVIM sample had a titer of $4,096 \mathrm{HAU}$ at $4^{\circ} \mathrm{C}$, which decreased to $8 \mathrm{HAU}$ after 60 minutes of incubation at $20^{\circ} \mathrm{C}$. This indicates that in addition to its HA activity, DVIM virions appear to possess a RDE-like activity which differs from the RDE activity shown for paramyxoand myxoviruses, which is not active at $20^{\circ} \mathrm{C}$.

Table 1. DVIM hemagglutination with red blood cells of various species, at different temperatures

\begin{tabular}{lccc}
\hline & \multicolumn{3}{c}{ HA titers at } \\
\cline { 2 - 4 } Species of red cell & $4^{\circ} \mathrm{C}$ & $20^{\circ} \mathrm{C}$ & $37^{\circ} \mathrm{C}$ \\
\hline Chicken & $<2$ & $<2$ & $<2$ \\
Goose & $<2$ & $<2$ & $<2$ \\
Rabbit & $<2$ & $<2$ & $<2$ \\
Guinea pig & $<2$ & $<2$ & $<2$ \\
Human " 0 " & $<2$ & $<2$ & $<2$ \\
Rat & 128 & $<2$ & $<2$ \\
Mouse & 128 & $<2$ & $<2$ \\
\hline
\end{tabular}

Avian red cells were prepared as 0.25 percent suspensions in PBS ( $\mathrm{pH} 7.3$ ), mammalian red cells were prepared as 0.5 percent in the same PBS

Table 2. Reduction of $H A$-titers at $20^{\circ} \mathrm{C}$

\begin{tabular}{lrr}
\hline & \multicolumn{3}{c}{ HA titers at } \\
\cline { 2 - 3 } Virus & $4^{\circ} \mathrm{C}$ & $20^{\circ} \mathrm{C}^{\text {a }}$ \\
\hline DVIM & 4096 & 8 \\
HVJ (Z st.) & 512 & 512 \\
Inf. A RI/5 & 1024 & 1024 \\
Inf. A /Victoria/3/75 & 32 & 32 \\
\hline
\end{tabular}

a Hemagglutination test were carried out at $4^{\circ} \mathrm{C}$ as usual, then the microplate was incubated at $20^{\circ} \mathrm{C}$, for 60 minutes

The HA titer was stable at $4^{\circ} \mathrm{C}$. However, $\mathrm{HA}$ appeared to be reversable only under some $\mathrm{pH}$ conditions, when incubated at $37^{\circ} \mathrm{C}$, as shown in Table 3 . The optimal $\mathrm{pH}$ for $\mathrm{HA}$ activity is relatively wide, whereas $\mathrm{RDE}$-like activity appeared optimal at a $\mathrm{pH}$ of about 7.4 and exhibited no activity at $\mathrm{pH} 6.5$, at $37^{\circ} \mathrm{C}$. The HA activity was stable at $37^{\circ} \mathrm{C}$, up to 24 hours, but was inactivated at $56^{\circ} \mathrm{C}$, within 20 minutes (data not shown). 
The stability of HA activity and infectivity of DVIM to various reagents is summarized in Table 4. Bromelain, a proteolytic enzyme which removes the club-shaped projections from the surface of other coronaviruses $(4,8,25)$, affected both HA activity and infectivity of DVIM. Trypsin did not affect HA activity or infectivity, while pepsin affected only $H A$ activity. The HA titer was reduced slightly by NP-40 treatment, and infectivity was destroyed. Ethyl ether destroyed both virus HA activity and infectivity.

Table 3. Effect of $p H$ on the $H A$-titers at $4^{\circ} \mathrm{C}$ and reduction of titers post incubation at $37^{\circ} \mathrm{C}$

\begin{tabular}{lccc}
\hline & \multicolumn{2}{c}{ HA-titer } & $\begin{array}{l}\text { Reduction } \\
\text { pH }\end{array}$ \\
\cline { 2 - 4 }$\left(\right.$ at $\left.25^{\circ} \mathrm{C}\right)$ & $4^{\circ} \mathrm{C}^{a}$ & $\begin{array}{l}\text { Post incubation } \\
\text { at } 37^{\circ} \mathrm{C}\end{array}$ & $\begin{array}{l}\text { rate } \\
\text { (a/b) }\end{array}$ \\
\hline 5.40 & 64 & 8 & 8 \\
5.55 & 64 & 8 & 8 \\
5.90 & 64 & 16 & 4 \\
6.20 & 128 & 128 & 1 \\
6.50 & 256 & 256 & 1 \\
6.82 & 256 & 128 & 2 \\
7.27 & 128 & 16 & 8 \\
7.43 & 128 & 8 & 16 \\
7.57 & 8 & 8 & 1 \\
7.87 & 4 & 4 & 1 \\
\hline
\end{tabular}

HA-titrations were carried out with 0.5 percent mouse red blood cells in indicated $\mathrm{pH}$, at $4^{\circ} \mathrm{C}$, thereafter the microplate was incubated at $37^{\circ} \mathrm{C}$ for 60 minutes

Table 4. The effect of chemical and proteolytio modification on $H A$ and infectivity of DVIM

\begin{tabular}{lcc}
\hline Treatment & HA-titer & Viral infectivity \\
\hline None & 128 & + \\
Trypsin & 128 & + \\
Pepsin & 32 & + \\
Bromelain & $<2$ & - \\
NP-40 & 96 & - \\
Ethyl-ether & $<2$ & - \\
\hline
\end{tabular}

Ethyl ether treatment of virus was carried out by mixing with an equal volume of ethyl ether at $4^{\circ} \mathrm{C}$ for 1 hour, and following removal of ethyl ether HA activity and infectivity were assayed. Enzyme treatment of purified virions was carried out by incubating purified virions at $37^{\circ} \mathrm{C}$ in PBS containing $50 \mathrm{~mm}$ dithiothreitol with trypsin, pepsin, or bromelain at $1 \mathrm{mg} / \mathrm{ml}$, respectively. After enzyme treatment, virions were pelleted through 30 percent $(\mathrm{w} / \mathrm{w})$ sucrose cushion and assayed for $\mathrm{HA}$ activity and infectivity. Nonidet P-40 (NP-40) treatment was carried out in the same manner as enzyme treatments, in PBS containing 1 percent NP-40 and $50 \mathrm{~mm}$ dithiothreitol. Infectivities were expressed as positive: + , and negative: -

\section{Further Characterization of Receptor Destroying Activity}

The data in Tables 2 and 3 indicate that DVIM virions agglutinate mouse RBCs at $4^{\circ} \mathrm{C}$, and the process was reversed at $37^{\circ} \mathrm{C}$. The present experiments were designed to characterize further the virus associated RDE-like activity which might have an effect on the receptor sites of RCBs. DVIM infection of BALB/c$3 \mathrm{~T} 3$ cells exhibits a cytopathic effect evidenced by the formation of syncytia. 
The infected cells exhibit virus-specific enzyme activities associated with these syncytia. Fig. 1 shows the elution kinetics of red blood cells from the syncytia, induced by DVIM 10 hours after infection, at $20^{\circ}$ and $37^{\circ} \mathrm{C}$ respectively. Approximately 70 to 80 per cent of RBCs were liberated within 30 minutes at $37^{\circ} \mathrm{C}$ while the liberation at $20^{\circ} \mathrm{C}$ progressed slowly. Therefore, the cell surfaces of DVIM-induced syncytia exhibit the same HA and RDE-like activities associated with virions.

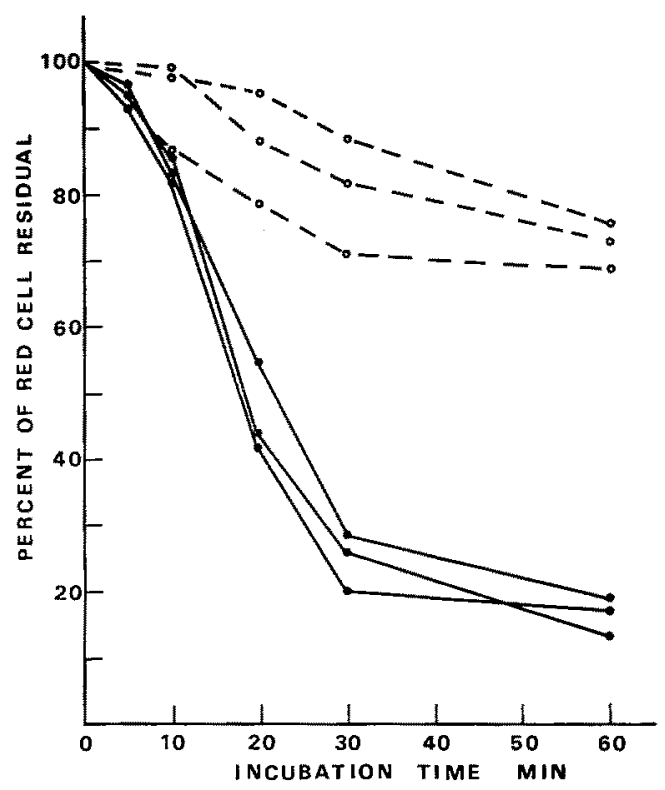

Fig. 1. The liberation of mouse red blood cells from the hemadsorbed syneytium, formed at 10 hours after inoculation with DVIM. Hemadsorbed syncytia were incubated at $37^{\circ} \mathrm{C}(-\bullet)$ or $20^{\circ} \mathrm{C},(0-\ldots)$. The liberation rate of red cells was expressed as the percentage of remaining cells on the syncytia, counted in the same photographic field at various incubation periods

If liberated $\mathrm{RBCs}$ are reexposed to DVIM-infected monolayers, no hemadsorption is observed. The same syncytia could again hemadsorb freshly prepared RBCs (Fig. 2). This implies that hemadsorption of DVIM does not correspond to "pseudo-hemadsorption" described by Bucknatl et al, (3). Furthermore, the elution of red blood cells from syncytia appears to be a result of enzymatie digestion of $\mathrm{RBC}$ receptors by a RDE-like activity situated on the syncytia surface. This activity was dependent upon incubation temperature, similar to RDE-like activity of DVIM virions.

To confirm the receptor destroying activity of DVIM, the effect of the purified virus on red blood cells was examined. Mouse RBCs treated with DVIM were reagglutinated by Influenza-A viruses or $\mathrm{HVJ}$, but could not be reagglutinated by DVIM virions (Table 5). In contrast, RDE treated mouse RBCs could still be fully agglutinated by DVIM (Table 6). Influenza-A hemagglutination of RBCs was reduced in proportion to the concentration of $\mathrm{RDE}$. 
Table 5. HA-titers determined with virus-treated mouse red blood cells

\begin{tabular}{lccc}
\hline \multicolumn{3}{c}{ HA-titers } \\
\hline & \multicolumn{2}{c}{ Red blood eell pretreatment } & \\
\cline { 2 - 4 } Virus & Inf.A/RI/5 & DVIM & Control \\
\hline DVIM & 2048 & 128 & 2048 \\
Inf. A/RI/5 & 32 & 4096 & 1024 \\
Inf. A/NJ/8/76 & 8 & 256 & 64 \\
HVJ & 512 & 1024 & 256 \\
\hline
\end{tabular}

Each virus ( $>5000 \mathrm{HA}$ ) was mixed with mouse RBCs (2.5 percent final conc.). Each mixture was incubated at $4^{\circ} \mathrm{C}$ for 3 hours, followed by incubation at $37^{\circ} \mathrm{C}$ for 4 hours. These preineubated RBCs were thoroughly washed with PBS and resuspended at 0.5 percent and then used for HA titration. Control RBCs were not pretreated with virions

Table 6. HA-titers determined with RDE-treated mouse red blood cells

\begin{tabular}{lrrrr}
\hline & \multicolumn{4}{c}{ RDE concentration $(\mathrm{mg} / \mathrm{ml})$} \\
\cline { 2 - 5 } Virus & 0.12 & 0.06 & 0.03 & Control \\
\hline DVIM & 256 & 256 & 256 & 256 \\
Inf.A/RI/5 & 4 & 8 & 32 & 64 \\
Inf.A/Vic./3/75 & $<4$ & $<4$ & $<4$ & 32 \\
HVJ & 64 & 32 & 32 & 32 \\
\hline
\end{tabular}

Mouse red blood cells were treated with RDE at indicated concentration, dissolved in $0.01 \mathrm{M} \mathrm{Ca-Borate} \mathrm{buffer} \mathrm{(} \mathrm{pH} 7.2$ ), at $37^{\circ} \mathrm{C}$ for 60 minutes, after which the cells were washed and resuspended as a 0.5 percent suspensions in PBS and used for HA titration. RDE was obtained from Vibrio cholerae variant of 558 strain filtrate (Takeda Pharm. Co. Osaka, Japan). Control RBCs were not treated with the RDE

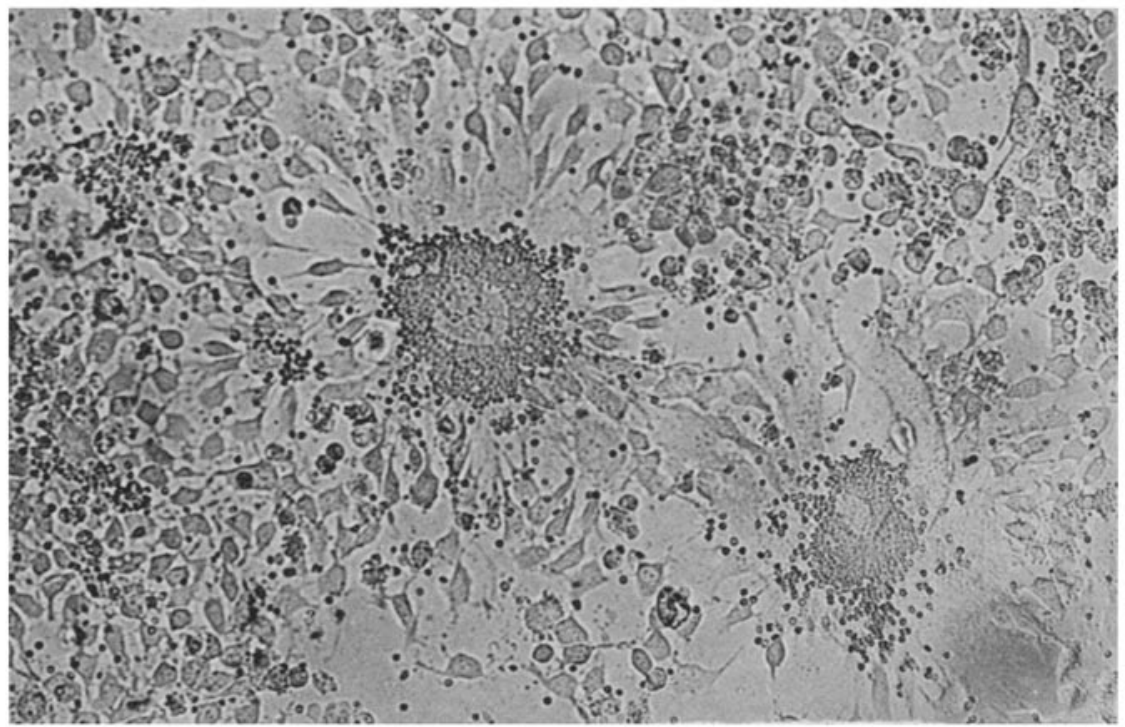

Fig. 2. Readsorption of freshly prepared RBC to previously exposed syncytia. Hemadsorbed syncytium which were incubated at $37^{\circ} \mathrm{C}$ to release $R B C$ for 60 minutes, were exposed to freshly prepared RBCs and photographed 
Above results strongly suggest that DVIM possesses an enzymatic activity which reacts with surface components of RBCs. However, this enzymatic action appears to differ from the bacterial neuraminidase and that of Influenza-A virions.

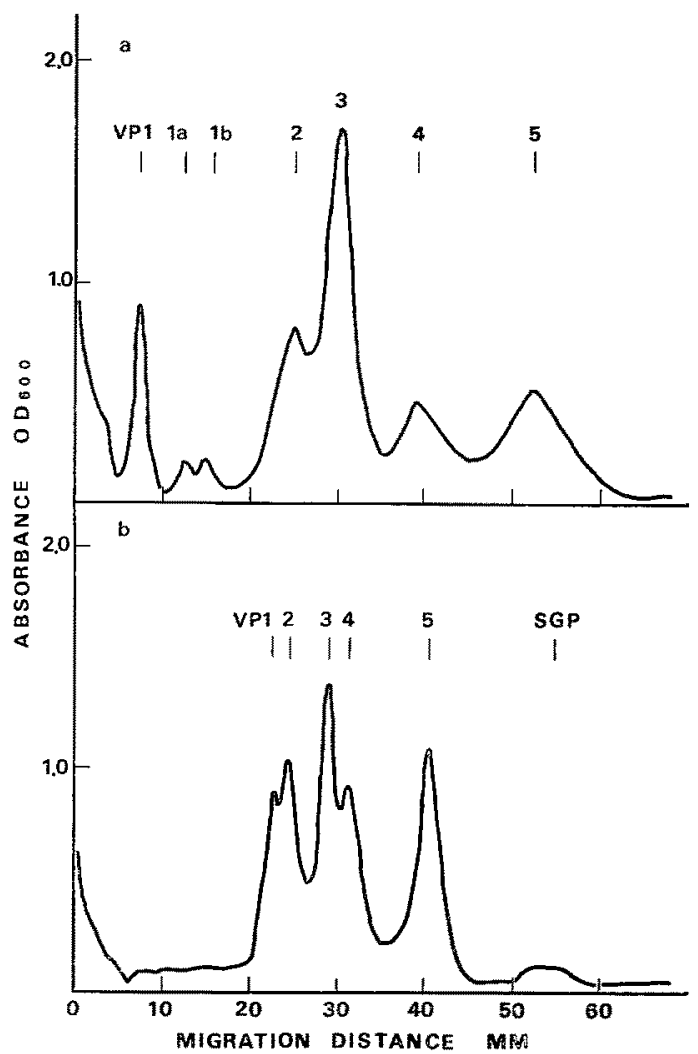

Fig. 3. Polypeptides of DVIM separated by 7.5 percent polyacrylamide gel electrophoresis. Gels were stained with Coomassie brilliant blue and scanned at $600 \mathrm{~nm}$. $a$ purified DVIM, $b$ purified HVJ

\section{Virus Polypeptide Analysis}

Since DVIM is a newly isolated coronavirus, its structural polypeptides have not been characterized. Therefore we analysed the virion polypeptides by SDSPAGE. Electrophoresed polypeptides, when stained with Coomassie brilliant blue, revealed a minimum of seven bands. A densitometer scan of stained polypeptides of DVIM and HVJ are shown in Figs. $3 \mathrm{~A}$ and $3 \mathrm{~B}$, respectively. The five major polypeptides of DVIM were designated as VP1 to VP5 in decreasing order of electrophoretic mobility, as shown in Fig. 3A. Two additional minor bands VP1 a and VP1b were observed between VP1 and VP2. The approximate molecular weight and molar ratios of the structural polypeptides, are presented 
in Table 7. Preliminary analyses indicated that three polypeptides, VP 1, VP $1 \mathrm{~b}$ and VP2 are glycoproteins, while VP2 reacted with oil-red-0, suggesting it may be a lipid-containing protein.

Table 7. Structural polypeptides of mouse enteric coronavirus (DVIM)

\begin{tabular}{|c|c|c|c|c|}
\hline \multirow[b]{2}{*}{ Polypeptide } & \multicolumn{2}{|c|}{$\begin{array}{l}\text { Approximate } \\
\text { MW }\left(\times 10^{3}\right)^{a}\end{array}$} & \multirow{2}{*}{$\begin{array}{l}\text { Relative } \\
\text { amount } \\
(\%)\end{array}$} & \multirow{2}{*}{$\begin{array}{l}\text { Pelative } \\
\text { molar }^{b} \\
\text { amount }\end{array}$} \\
\hline & Mean & Range & & \\
\hline$\overline{\mathrm{VP} 1}$ & 139 & $126-147$ & 7 & 2.1 \\
\hline VP $1 \mathrm{a}$ & 110 & $100-116$ & 4 & 1.5 \\
\hline VP $1 b$ & 100 & $88-105$ & 4 & 1.7 \\
\hline VP2 2 & 68 & $65-72$ & 18 & 10.9 \\
\hline VP3 & 53 & $51-59$ & 26 & 20.3 \\
\hline VP 4 & 38 & $34-41$ & 17 & 18.5 \\
\hline VP5 & 22 & $21-24$ & 24 & 45.1 \\
\hline
\end{tabular}

a Mean of minimum for 20 gels from 7 electrophoresis runs

b Relative amount divided by corresponding molecular weight and normalized to a percentage

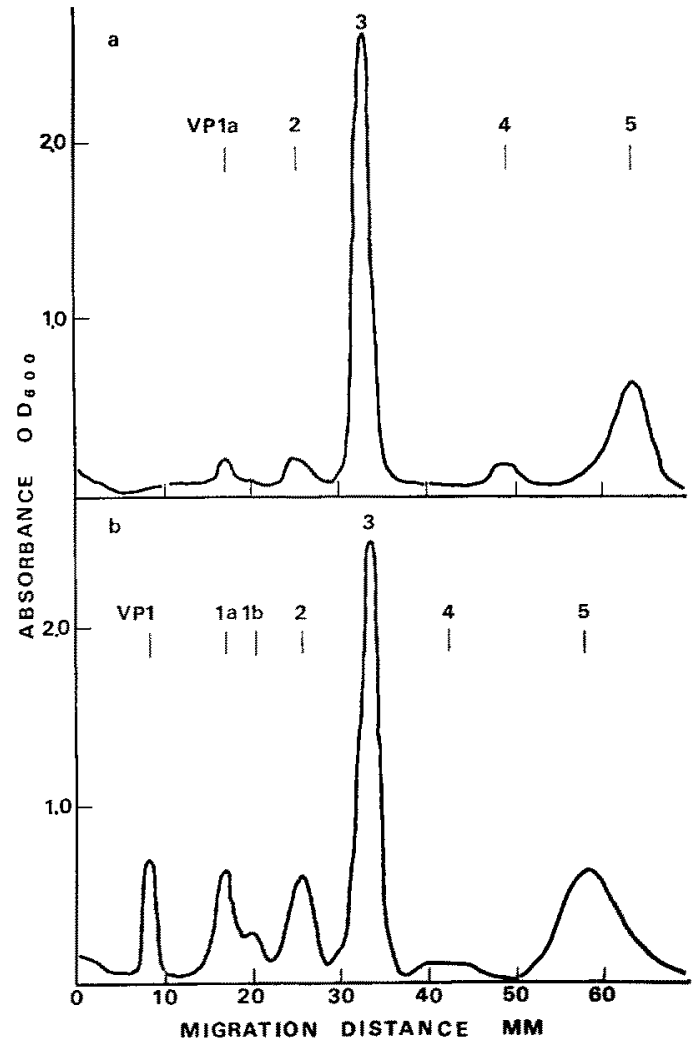

Fig. 4. Densitometer tracing of bromelain treated and untreated DVIM. Purified virions were treated with 0.1 percent bromelain at $37^{\circ} \mathrm{C}$ for 15 minutes and repurified as described in Materials and Methods. $a$ repurified DVIM, $b$ control preparation 


\section{Effect of Bromelain on the Structural Polypeptides}

A densitometer scan of a stained polyacrylamide gel of the polypeptides of virus particles treated with bromelain $\left(1.0 \mathrm{mg} / \mathrm{ml}\right.$ at $37^{\circ} \mathrm{C}$ for 15 minutes $)$ is shown in Fig. 4. As ean be seen from this figure, VP1 and VP1 $b$ were digested by the bromelain treatment, suggesting that these polypeptides are found on the surface of the virion. Polypeptides VP1 a and VP2 were also reduced, and only trace amounts of them were still observed, suggesting these polypeptides may also be surface polypeptides. VP3 was unaffected by bromelain treatment, suggesting that it represents an "inner core" protein.

\section{Diseussion}

Direct HA (i.e. without pretreatment of the virus) and hemadsorption have been described for several coronaviruses, OC-43 (11, 12), HEV $(6,20)$, IBV (1), and bovine coronavirus (2). The hemagglutinating ability of OC-43 required several passages in suckling mouse brain (12), and Massachusetts strain of IBV (1) required both sucrose gradient purification and digestion with phospholipase $\mathrm{C}$ for activation. The HA of DVIM, reported here, was detectable directly in the culture fluid. The ratio of infectivity to HA varied between 1.2 and $3.1 \times 10^{4} \mathrm{TCID}_{50} /$ $0.1 \mathrm{ml} / \mathrm{HA}$ unit. DVIM hemagglutinated the RBCs of only two species tested, while other coronaviruses, OC-43, HEV and IBV, were less specific. Accordingly, HA of DVIM was expressed only using two types of red blood cell species, mouse and rat, and was also detectable at low temperatures in a stable pattern.

The formation of "prozone" described by Bingrianc et al. (1) was not observed for DVIM. The instability of HA and hemadsorption at $20^{\circ} \mathrm{C}$ suggests that a viral enzyme may be responsible for uncoupling the virus from the red blood cell receptor. The possible enzymatic activity of DVIM was demonstrated on homologous virus receptors of mouse $\mathrm{RBCs}$ without any effect on receptors for heterologous viruses, Influenza-A and HVJ. Furthermore, it was also shown that bacterial neuraminidase (RDE) had no effect at all on the receptor for DVIM; nevertheless, the receptors for influenza-A viruses were destroyed by the same treatment. Additionally, even after purification through a sucrose density gradient, DVIM retains its receptor-destroying activity, thereby showing that this activity is viral-specific and associated with virions. Our preliminary results strongly suggest the existence of some type of receptor-destroying enzyme such as that of Influenza $\mathrm{C}$ virus $(10,13)$.

The optimal $\mathrm{pH}$ of DVIM HA activity was distinet from that of the receptordestroying activity. It has not been determined whether these activities may reside on a single polypeptide or on two different polypeptides. Because the surface projections of DVIM are somewhat different morphologically compared to other coronaviruses, it will be of interest to study the exact nature of the hemagglutinating and receptor-destroying activity of DVIM. The receptor-destroying activity of DVIM appears to be unique, when compared to that of ortho- and para-myxoviruses.

Purified DVTM contains seven species of polypeptides, five major and possibly two minor polypeptides. These results compare favorably to those obtained for human coronavirus $\mathrm{OC} 43$ (8), IBV (14), bovine coronavirus LY.138 (7) and other 
murine coronaviruses MHV-3 (16) and JHM (27). The elassification of the polypeptides of DVIM as glyco- or glycolipoprotein must be considered as tentative at this point since the chemical nature of these complexes cannot be precisely defined by differential staining techniques. The number and size of glycoproteins of coronaviruses which have been reported previously by many investigators, were shown to vary. It appears that our VPI (MW 139,000) corresponds to a large polypeptide ( $M W 150,000-200,000)$ reported for other coronaviruses (4, 8, 9, $15,16,19,24,25,27)$, because it is glycosylated and appears to be situated on the surface of the virion. Other DVIM virion polypeptides also appear to be surface glycoproteins. Furthermore, some of the investigators agree that coronaviruses contain a polypeptide having an approximate molecular weight of 50,000 , corresponding to our VP3, which is not glycosylated and tends to comprise a large proportion of the virus protein $(4,15,19,25)$. Polypeptide VP3 represents 26 percent of virus protein and is not affected by bromelain digestion at all. This suggests that VP3 is also located in the "inner core" $(5,19,25)$ of the virion. Although a considerable amount of VP4 was not observed in Fig. 4, the possibility that the VP4 could be an artifact produced by different conditions of reduction (24), still remains unexplained.

\section{Reierences}

1. Binghair, R. W., Madge, M. H., Tyrreld, D. A.: Hemagglutination by avian infectious bronchitis virus - a coronavirus. J. gen. Virol. 28, 381-390 (1975).

2. Bridger, J. C., Caul, E. O., EgGlestone, S. I.: Replication of an enteric bovine coronavirus in intestinal organ eultures. Areh. Virol. 57, 43-51 (1978).

3. Bucknati, R. A., Kalica, A. R., Chanook, R. M.: Intracellular development and mechanism of hemadsorption of human coronavirus, OC43. Proc. Soc. exp. Biol. Med. 139, $811-817$ (1972).

4. Garwes, D. J., Pocock, D. H.: The polypeptide structure of transmissible gastroenteritis virus. J. gen. Virol. 29, 25-34 (1975).

5. Garwes, D. J., Pocock, D. H., Puke, B. V.: Isolation of subviral components from transmissible gastroenteritis virus. J. gen. Virol. 32, 283-294 (1976).

6. Greio, A. S., Mitchell, D., Corner, A. H., Bannister, G. L., Meads, E. G., JULIAX, R. J.: A hemagglutinating virus produeing encephalomyelitis in baby pigs. Canad. J. comp. Med. 26, 49-56 (1962).

7. HaJer, I., Storz, J.: Structural polypeptides of the enteropathogenic bovine coronavirus strain LY-138. Arch. Virol. 59, 47-57 (1979).

8. Hierholzer, J. C., Palmer, E. L., Whiteield, S. G., Kaye, H. S., Dowdle, W. R.: Protein composition of coronavirus OC 43. Virology 48, 516-527 (1972).

9. Hierholzer, J. C.: Purification and biophysical properties of human coronavirus 229 E. Virology 75, 155-165 (1976).

10. Hrrst, G. K. The relationships of the receptors of a new strain of virus to those of the mumpus-NDV-influenza group. J. exp. Med. 91, 177-184 (1950).

11. Kapikian, A. Z., James, H. D., JR., KellY, S. J., King, L. M., VaUGEN, A. L., Chanock, R. M. Hemadsorption by coronavirus strain OC-43. Proc. Soc. exp. Biol. Med. 139, $179-186$ (1972).

12. KAye, H. S., DowdLE, W. R. : Some characteristics of hemagglutination of certain strains of "IBV-like" virus. J. inf. Disease 120, 576-581 (1969).

13. Kendat, A. P.: A comparison of "influenza C" with prototype myxoviruses; Receptor-destroying activity (neuraminidase) and struotural polypeptides. Virology 65, 87-99(1975).

14. Machavghton, M. R., Madge, M. H.: The polypeptide composition of avian infectious bronchitis virus particles. Arch. Virol. 55, 47-54 (1977). 
15. Macnaughton, M. R., Madge, M. H., Davies, H. A., Dourmaserkix, R. R.: Polypeptides of the surface projections and the ribonucleoprotein of avian infectious bronchitis virus. J. Virol. 24, 821-825 (1977).

16. Macnaughton, M. R.: The polypeptides of human and mouse coronaviruses. Arch. Virol, 63, 75-80 (1980).

17. Marzes, J. V.: Acrylamide-gel electrophorograms by mechanical fractionation; Radioactive adenovirus protein. Science 151, 988 - 990 (1966).

18. McInтosh, K.: Coronavirus; A comparative review. Curr. Top. Microbiol. Immunol. 63, 85-129 (1974).

19. Pocock, D. H., Garwes, D. J.: The polypeptides of hemagglutinating encephalomyelitis virus and isolated subviral particles. J. gen. Virol. 37, 487-499 (1977).

20. Peinsaert, M. B., Callebaut, P. E.: Characteristics of coronavimus causing vomition and wasting in pigs. Arch. ges. Virusforsch. 44, 35-50 (1974).

21. SATO, K., MARU, MT,, WADA, T.: Some characteristics of corona-like virus isolated from infant mice with diarrhea and inflamentory submaxillary gland of rats (in Japanese). Virus 26, 97 (1976).

22. Shapiro, A. L., Vinuera, E., Matzed, J. V.: Molecular weight estimation of poly. peptide chain by electrophoresis in SDS-polyacrylamide gels. Biochem. Biophys. Res. Commun. 28, 815-820 (1967).

23. Shrmizu, K., Shimizu, Y. K., Kонama, T., Ishida, N.: Isolation and characterization of two distinct types of HVJ (Sendai virus) spikes. Virology 62, 90-101 (1974).

24. Sturman, L. S.: Characterization of a coronavirus. I. Structural proteins: effects of preparative conditions on the migration of protein in polyacrylamide gels. Virology 77, 637-649 (1977).

25. Sturman, L. S., Holmes, K. V.: Characterization of a coronavirus. 2. Glycoproteins of the viral envelope; Tryptic peptide analysis. Virology 77, 650-660 (1977).

26. Tyrrell, D. A. J., Almeida, J. D., Berry, D. M., Cunntrgham, C. H., Hamre, D., Hofstad, M. S., Matiucci, L., MoTwtosh, K.: Coronaviruses. Nature 200, 650 (1968).

27. Wege, H., Wege, Hanna, Nagashma, K., ter Meulen, V.: Structural polypeptides of the murine coronavirus JHM. J. gen. Virol. 42, 37-47 (1979).

Authors' address: Dr. K. Suciyama, Department of Microbiology, University of Alabama in Birmingham, University Station, Birmingham, AL 35294, U.S.A. 